\title{
Telefonitis: unge danskeres brug af telefonen i IT-tidsalderen
}

\author{
Gitte B. Stald
}

Den udbredte brug af mobiltelefoner har sat fornyel fokus pai telefonens betydning ivores tid. Som folge af den informationsteknologiske udvikling cendrer telefonen karakter fra at vere en kanal for kommunikation til at vare et medie for flere funktioner, samtidig med at dens konkrete og symbolske betydning forstarkes. Dette kan i serlig grad afleses i storre børns og unges brug af telefonen, der dels er karakteriseret ved stor selvfolgelighed, dels ved at have en betydning, der rakker ud over funktionen. På baggrund af kvantitative og kvalitative data underseges i artiklen telefonens funktioner: den er markor af ungdomskultur, den er garant for tryghed, og den muliggar fastholdelse af sociale og personlige relationer. Telefonen befordrer etableringen af et virtuell rum, hoor intimitet og fortrolighed er mulig. Set $i$ lyset af den informationsteknologiske udvikling, der har bragt e-mail, chat og andre former for on-og offline kommunikation ind i de fleste unge danskeres tiluerelse, er det interessanl, at lelefonen har fasthold og endog forsterket sin betydning.

The child and the teenager understand the telephone, embracing the cord and the ear-mike as if they were beloved pets. What we call "the french" phone, the union of mouthpiece and earphone in a single instrument, is a significant indication of the French liason of the senses that English-speaking people keep firmly separate. French is "the language of love" because it unites voice and car in an especially close way, as does the telephone (McLuhan 1964/1994: 266).

The telecommunications network of the second century will undoubtedly do many great and wondrous things, only some of which we can now guess. Yet we can say with confidence that the institutions and societies that press forward most vigorously in the use of this technology will tend to shape the way of life in that century (Pool 1977: 9).

Op mod jul 1998 blev der i Danmark solgt omkring 120.000 mobiltelefoner, hvoraf langt de fleste var af typen med taletidskort og i den billige ende af et stort udvalg. Det er rimeligt at antage, selv om det ikke umiddelbart kan dokumenteres, at et stort antal af disse telefoner er endt under juletryet som gaver til store born og teenagere, der således er blevet begavet med egen mobil kommunikationsen- hed, samtidig med at både de og deres forældre undgår økonomisk og praktisk besvær med telefonabonnement og regninger hvert kvartal. Efter at denne type mobiltelefoner er kommet på markedet i Danmark fra sommeren 1998, er andelen af store børn og unge, der er i besiddelse af en mobiltelefon, vokset voldsomt. Ud fra cn økonomisk betragtning skyldes dette dels det umiddelbart tiltrakkende i friheden for abonnement og i separat okonomi i forhold til familie-telefoneme, dels at priserne i den billige cnde af produkt-udbuddet xkvivalerer, hvad mange anser for at vare passende gaver. Ud fra en behovsmassig betragtning afspejler antallet af born og unge med egen mobiltelefon dels en tilpasning til ogede muligheder for kommunikation, dels mobiltelefonens betydning som reprasentation af ungdomskultur.

Mobiltelefonmarkedet er eksploderet med nye produkter, der såvel omfatter forbedringer af eksim sterende tjenester săsom SMS (Short-Message System) og hastighed for transmission, som nye anvendelsesmuligheder, for eksempel opkobling til Internettet og MP3-tilkobling, så man kan høre musik via telefonen. Udsigten fra branchens bjergtop er, at mobiltelefonen i lobet af ganske kort tid vil kunne integrere de fleste af de funktioner som 
telefon, computer, Internet, radio og tv tilsammen tilbyder. Forste station pá vejen mod det optimalt konvergerede medium er WAP-telefonen (Wireless Application Protocol), der muliggor opkobling til en forsimplet, "grafik-let《 udgave af Internettet. Også udviklingen af fastnettelefoncme udvider tjenesterne med nye digitale teknikker såsom ISDN, som muliggor lokale netvark, lokale mediecentraler med compuier, Here telefoner, fax og telefonsvarer på samme linie, genopkald og nummervisning. Sävel den traditionelle telefon som den mobile udvikler sig til at vare digitale centraler for en rakke informations- og kommunikationstjenester til brug i hverdagslivet.

Det omfattende salg af mobiltelefoner med taletidskort i tilslutning til udviklingen af ny teknom logi, der forekommer at gå lige så staekt som highspeed-tjenesteme på GSM-nettet, og ikke mindst markedsforingen af disse tjenester, har făet pressen og diverse institutioner til at stille ind på borns og unges brug af mobiltelefoner. Der fokuseres iszer på, hvorledes bernene og de unge i enhver tenkelig situation ringes op eller ringer, og i hvor hoj grad de ringende telefoner og den opmarksomhed, de fär, forstyrrer - for eksempel i skoletiden:

Mobiltclcfoner er stadig en dejlig ting, når bare de bruges fornuftigt. Eleverne er selvfolgelig stadig velkomnc til at have mobiltelefon med i skole - på eget ansvar. MEN den skal vare slukket i timeme. Det er yderst forstyrrende for klassens koncentration om undervisningen, hvis mobilen giver lyd fra sig i timerne. Sker dette - og det gar det lidt for ofte - har vi besluttet, at telefonen indleveres pả kontoret til senere afhentning (Nyhedsbrev 1999).

Et ăr tidligere omhandlede en lignende advarsel i nyhedsbrevet Tamagotchier, og ăret for gjaldı det rulleskøjter. Dette peger pă mobiltelefonernes lighed med legetøj, med et modefanomen, der har bestemte funktioner; men det antyder også, at fascinationen af og opmarksomheden omkring produktet pả langt sigt kan vare flygtig. Markedet og interessen for mobiltelefonerne vil måske falde til ro, når effekten af fremvisningsvaerdien og en intensiv markedsforing aftager, og når mobiltelefonen er blevet en selvfolgelighed for de fleste. Saledes har også teleselskaberne rasonneret, og en lang rakke tjenester lanceres, sa blandingen af nyhedsvardi, teknilfascination og integration i især teenageres kommunikationsmønstre og kulturelle univers til stadighed opdateres.

Borns og unges interesse for mobiltelefoner skal også knyttes sammen med en andret praksis i forhold til tele-kommunikation. De fleste har oplevet, hvorledes mobiltelefoners karakteristiske ringetoner bryder lydbilledet i in falles anonym tilstedevarelse: i bussen/toget, i supermarkedet, på stranden eller i biografen. Privatheden brydes i disse situationer således, at den interpersonelle kommunikation ikke lengere kun er privat men også offentlig, ved at mediet gor opmarksom på situationen og ved at omkringstående delvist indvies i samtalens indhold. Desuden virker situationen oftest tilbage på kommunikationssituationen, sålcdes at de talende er bevidste om andres opmarksomhed.

Udviklingen på mobiltelefonmarkedet og mobiltelefonens popularitet blandt store born og unge har synliggiort telefonen pă en helt konkret măde, hvor den hidtil har veret noget overset indenfor børne- og ungdomsmedieforskningen og medieforskningen generelt. Siden de Sola Pool redigerede The Social Impact of the Telephone (Pool 1977), en telefonen og dens betydning isxer blevet analyseret is ammenhang med de teknologiske mediers sociale betydning, således som Meyrowitz har gjort det i nogen grad inspireret af McLuhans ideer om teknologi som wextensions of mank (Meyrowitz 1985, McLuhan 1964/1994). McLuhan beskriver pracist med en næsten poetisk tone telefonens sociale og kulturelle betydning for born og unge. Meyrowitz udvikler det teoretiske afsæt for at diskutere sammenhrngen mellem teknologisk udvikling og sociale forandringer, og han udvider analysen til at omfatte forholdet mellem sociale relationer og social og kulturel identitet også i forhold til borns og unges udvikling. I denne artikel har jeg derfor kunnet stotte mig til en rakke af Meyrowitz'analyser.

Inden for kommunikationsteori, isar interpersonel kommunikation, har telefonen sin selvfolgelige plads i typologiseringen af kommunikationsformer og -forhold, men her er den ofte afgrenset til betydningen af redskabsmassig funktion i sociale relationer og forandringsprocesser, mens den kulturelle eller psykologiske betydning nedtones eller glemmes. Det samme galder IT-forskningen, hvor telefonens karakteristika i forhold til tid, rum og interaktivitet helt logisk sammenlignes med kommunikation og virtuelle relationer i cyberspace. Jo synligere telefonen bliver i ungdomskultureme, jo mere sandsynligt er det dog, at telefonen vil blive genstand for sarlig forskningsmaessig interesse. For eksempel har en gruppe australske medieforskere undersegt australske teenageres tele- 
fonbrug såvel i forhold til udviklingen af sociale relationer som til indholdets spejling af ungdomskulturelle karakteristika (Gillard, Wale og Bow 1998). Den øgede forskningsinteresse for digitaliseringen af medierne og mediekonvergensen giver imidlertid også ny interesse for kommunikationsteknologien i dens nye former. I et forskningsprojekt ved Malmö Högskolas Afdeling for Interaktive Studier om ungdommen i byrummet, "To be located «, tillagges mobiltelefonen stor betydning for de unges følelse af tilhorsforhold såvel i geografisk som social, kulturel og psykologisk forstand. Resultaterne fra dette og andre lignende forskningsprojekter kan forhảbentlig på sigt bidrage med nye tcoretiske $o g$ analytiske redskaber til forstáelse af de forandringer, integration af ny medictcknologi medforer $i$ de ungdomskulturelle universer og de perspektiver, forandringerne giver for unges forstaelse af forholdet mellem globalitet og lokalitet, mellem national identitet og geografisk tilstedevarelse og mellem social, kulturel og psykologisk identitet.

Telefonen er allestedsnarvarende, nodvendig, integreret $i$ alle danskeres arbejds- $o g$ fritidsliv. Som kommunikationsmiddel er telefonen en selvfolgelighed, upăfaldende i sin tilstedevarelse, men central i sin funktion (Stald 1997:94), som drengen her udtrykker det:

Telefonen, det er noget af det man bruger flest gange i antal, men ikke i tiden synes jeg, men altsă, det er noget ... du ringer jo hele tiden og tager telefonen hele tiden, ikke, det er også noget af det. Jeg tanker bare ikke på det. Det er en selvfolge at have telefonen. Man kan bare ikke forestille sig, at den ikke er der (Janus, 15 år).

Kun enkelte af de godt hundrede deltagere i den undersogelse, der isar udgor det empiriske grundlag for denne artikel, finder ikke telefonen specielt vigtigt eller kan ikke se fordelene ved at have en mobiltelefon. Under interviewet udvikler deltagerne deres refleksioner over telefonbrugen ud fra overvejelser og prioriteringer af brug og behov. De Heste konkluderer, at det er vanskeligt at forestille sig tilvarelsen uden telefoner. Fravaret, ikke tilstedevarelsen af telefonen, er problematisk, ja ligefrem farlig:

Hvis jeg ikke havde en telefon, så havde jeg et problem. ... En telefon, det er en god måde at alarmere på, et eller andet, năr der sker noget, altså ikke at have cn telefon, det er farligt, sa skulle man bo i en eller anden hytte ude iskoven, i cn negerhytte i middelalderen, eller et eller andet, i stenalderen, jeg ville ikke sådan bo alene hjemme, hvis jeg lige var flyttet hiemmefra uden telefon, wha nej, det ville vare meget irriterende (Regitze, 12 ăr).

For pigen her hanger adgangen til telefonen sammen med vores moderne tilvarelse. Et liv uden telefon er kun tænkeligt under helt fremmede betingelser eller $\mathrm{i}$ en anden tidsalder. Telefonen er for hende et helt nodvendigt redskab for at opretholde kontakt med andre, som varn mod ensomhed og som sikkerhed i krisesituationer. De to citater resumerer tilsammen de trak, der karakteriserer såvel mediets funktion som den praksis og kultur, der knytter sig til børnenes og de unges telefonbrug. Dette fokus danner afsat for diskussionen i artiklen: hvor meget og med hvilke formål bruges telefonen i hverdagslivets forskellige kommunikationssituationer? Hvilken status har telefonen istore borns og unges kulturelle universer? $\mathrm{Og}$ hvilke funktioner opfylder telefonen på et symbolsk plan, der rækker ud over selve den kommunikative handling?

Det er ikke tilstrakkeligt at se på telefonbrugen isoleret, når unge danskeres medierede interpersonelle kommunikation skal analyseres, idet der blandt andet som folge af en omfattende digitalisering af de elektroniske medier foregâr en stadig storre integration mellem forskellige medietyper og brugen af disse. Derfor belyser artiklen ogsa , hvordan bornenes og de unges telefonbrug ser ud på baggrund af en generel informationsteknologisk udvikling, hvor mulighederne for medieret interpersonel kommunikation er udvidet med tilbud som e-mail og online kommunikation.

\section{Adgang}

Meyrowitz påpeger, at det efterhånden cr umuligt at isolere sig i sảvel sin fysiske »borg « som i sit psykologiske frirum, fordi telefonen anses for en uomgangelig nodvendighed. Det kan opfattes som en fornarmelse mod venner og kolleger, hvis man ikke sørger for at vare i nerheden af en telefon (Meyrowitz 1985:147). Vi er i mange af vore hverdagssituationer afhengige af at vare »online «, at vi kan nås og kan nă, en realitet, der forstarkes proportionalt med IT-udviklingen.

Danmark er et af de lande i verden, der har storst dxkning med hensyn til savel telefonlinier som Internetadgang per indbygger (International Telecommunication Union, ITU 1997). Ved udgan- 
gen af 1998 var der i Danmark knap 66 fastnetabonnementer per 100 indbyggere, og godt $36 \mathrm{mo-}$ bilabonnementer per 100 indbyggere (Telestyrelsen 1998). I starten af år 2000 er det samlede abonnementtal cndnu hojere, iswer som folge af stor stigning $i$ antallet af internet-adgange og udbredelsen af mobiltclefoner. Faktuelle tal kan dog ikke bekrxftes af telesclskaberne, der konkurrerer starkt. Konkurrencen har indflydelse på bevagelserne på markedet og ikke mindst, qua billigere samtalepriser, på danskernes adgang til og brug af diverse tjenester.

En landsdek kende, kvantitativ undersøgelse af borns og unges mediebrug (Drotner 2000) foretaget for Center for Borne- og Ungdomsmedicr (CUM) viser, at dxkningen for adgang til fastnettelefon i hjemmet ligger på omkring $95 \%$, og at nasten tre ud af fire har adgang til mobiltelefon (Drotner 2000). De fem procent af familierne, der ikke har adgang til fastnettelefon, har for de flestes vedkommende mobiltelefon, mens kun ganske få er telefonlose. Kun enkelte 6-7-ărige har egen fastm nettelefon og slet ingen har mobiltelefon, men tallet stiger med alderen for begge former for telefoner. Omkring hver tiende af de 9-10-ärige og hver tredie af de 15-16-arige har adgang til telefon pä varelset. Tallene for mobiltelefon er ganske lave for de 9-10-årige, mens cirka hver tiende af de 1516-årige har mobiltelefon. Som navnt er andelen af born og unge, der har adgang til mobiltelefon, givetvis vokset siden data blev indsamlet. Tallene fra CUM's undersøgelse bekreftes af Socialforskningsinstituttets undersogelse af 7-15-åriges fritidsaktiviteter 1998 (Fridberg 1999), som viser en stim gende tendens i forhold til CUM's undersøgelse for adgangen til mobiltelefon og Internet individuelt og i hjemmet.

Ifolge Danmarks Statistiks undersogelse Pcere og adgang til Internet fra 1999 er andelen af familier med adgang til Internet mere end firedoblet fra forăret 1997 til foräret 1999 fra $8 \%$ til $33 \%$ (Danmarks Statistik 1999). Dette indikerer, at der er sket en kraftig stigning $\mathrm{i}$ anvendelsesmulighederne for den almindelige dansker i forhold til kommunikation, informationssegning, handel og underholdning. Bornefamilier har oftere end familier uden born adgang til Internet, hvilket bekrxfter, at form aldre ofte anskaffer ny teknologi for at fremtidssikre bormene og give dem mulighed for at vare med (Stald 1998). Men selv om den nye teknologi isar vinder indpas blandt unge og $\mathrm{i}$ bornefamilier, er der generelt stadig flere voksne, der finder mo- biltelefon og Internet praktisk såvel i arbejds- som fritidsliv. Med foraldregenerationens storre inddragelse af moderne informationsteknologi i hverdagslivet sker der en holdningsendring i forhold til de unges anvendelse af teknologien. Mange voksnes forste forskrakkede holdning til de unges overtagelse af og begejstring for ny teknologi som Internet og mobiltelefoner er ved at tage af og finde vej til nye omráder - for eksermpel nye integrerede medieformer eller udbredelse af virtual reality-teknologi på ungdomsvarelset.

Uden for hjemmet har de fleste danske born og unge adgang til Internet på udddannelsesstedet, biblioteket eller på cybercafecr. Omkring halvdelen af de 12-16-ărige har brugt Internettet pa biblioteket, og over halvdelen har brugt det på skolen ifolge CUM's undersagelse (Drotner 2000). Generelt har drengene hurtigere adgang til mere teknologi end pigerne, bortset fra de traditionelle telefoner, som befinder sig på 39\% af de 15-16-årige pigers varclser mod kun $28 \%$ af drengevarelserne. Det vil vaere interessant at se, hvorledes udviklingen pâ mobiltelefonområdet påvirker denne fordeling, men aktuclt findes der ikke tal for dette.

Ifolge CUM's undersøgelse er der ingen af de 6 10 -årige og kun mellem 5 og $15 \%$ af de 12-16-ärige, der bruger e-mail i skolen. $15 \%$ af de 15-16-årige drenge og $6 \%$ af pigerne bruger e-mail i skolen, så her er drengene igen de flittigste brugere. I hjemmet bruges e-mail bruges lidt oftere, af mellem $8 \%$ og $17 \%$ af de 12-16-årige. Her udlignes kønsforskellen dog noget, hvilket også er tilfaldet med brug af Internettet generelt. Blandt de piger og drenge, der bruger computer i hjemmet - relativt ferre piger end drenge - er der lidt tlere piger end drenge, der bruger Internettet (tabel 1).

\section{Markedsforing}

Den intensive markedsforing af et utal af mere eller mindre avancerede mobiltclefontyper viser, at der er tale om et felt i stor konkurrence, både hvad angår hardware og service. Selvstandige abonnementer til born og unge er dyre losninger for forddrene, og de fleste fastnettelefoner, der findes rundt om på bornevarelscrnc, er således ckstra-apparater tilsluttet samme linie som husstandens. Men med mobiltelefonerne, isar taletidskorttelefonerne, har markedet åbnet sig mod over en halv million potentielle kunder. Ganske vist har ingen af tem lefonselskaberne pă det danske marked endnu markedsfort særlige telefoner til små born, med le- 


\begin{tabular}{|c|c|c|c|c|c|c|c|c|c|}
\hline & \multirow[t]{2}{*}{ l alt } & \multicolumn{2}{|c|}{ 6-7 àr } & \multicolumn{2}{|c|}{$9-10 \mathrm{ar}$} & \multicolumn{2}{|c|}{$12-13 \operatorname{arr}$} & \multicolumn{2}{|c|}{ 15-16 âr } \\
\hline & & dreng & pige & dreng & pige & dreng & pige & dreng & pige \\
\hline $\begin{array}{l}\text { Telef./ } \\
\text { Hjem }\end{array}$ & 95 & 99 & 100 & 91 & 91 & 91 & 95 & 96 & 96 \\
\hline $\begin{array}{l}\text { Telef./ } \\
\text { værelse }\end{array}$ & 17 & 1 & 2 & 13 & 10 & 25 & 20 & 28 & 39 \\
\hline $\begin{array}{l}\text { Mobil/ } \\
\text { hjem }\end{array}$ & 62 & 73 & 63 & 59 & 52 & 61 & 62 & 59 & 66 \\
\hline $\begin{array}{l}\text { Mobil/ } \\
\text { varelse }\end{array}$ & 3 & 0 & 0 & 3 & 2 & 3 & 3 & 11 & 8 \\
\hline $\begin{array}{l}\text { Internet/ } \\
\text { hjem }\end{array}$ & 25 & 28 & 11 & 31 & 24 & 32 & 23 & 26 & 26 \\
\hline $\begin{array}{l}\text { Internet/ } \\
\text { varelse }\end{array}$ & 4 & 2 & 0 & 7 & 3 & 10 & 0 & 12 & 3 \\
\hline
\end{tabular}

getojsudsende, ct spcciclt tastatur og ikoner i stedet for tekst på skarmen, således som det er tilfaldet i for eksempel $\varnothing_{\text {strig, Portugal og Sverige. }}{ }^{2}$ Men selv uden de yngste born er det potentielle marked meget stort. Og telefonerne markedsfores på netop det, der karakteriserer bornenes og de unges egne opfattelser af, hvad de kan bruge telefonen til: at holde forbindelse med venner og familie, at kume fa hjxlp i krisesituationer og som udtryk for livsstil.

Markedsforingen af Internettet finder i hej grad sted $\mathrm{i}$ en selvforstarkende bevagelse som folge af den »hypek, der omgiver nettet (Nissen 1998) og i kraft af et hastigt accellererende antal tjenester, der er rettet mod almindelige menneskers almindelige behov. Op mod julen 1999 blev der sat fokus pá handel med dagligvarer, legetoj og diverse andre varetyper beregnet på julcgaver via Internettet. Virksomheder, der ikke sielger deres produkter via Internettet, $\gg$ trues med, at de pä (endog kort) sigt ikke vil kunne klare sig i konkurrencen med de fremsynede virksomheder, der markedsforer produkter og handler via Internettet. Det samme gelder offentlige institutioner. Intemettilslutninger salger săledes stort set sig selv, stottet af traditionelle kampagner for salg af modems og abonnementer, som isser korer på pris og hastighed.
Også de nyeste mobiltelefoner omgives af en sarlig whype hos en bestemt gruppe teenagere, og säledes kommer brugerne sclv til at forstarke branchens markedsforing i et uformelt informationsnet og trendsetting, der breder sig meget hurtigt. Dobbeltheden af markedsforing og påvirkning via de unges egne netvark betyder imidlertid, at mobiltelefonen generelt făr stadig storre udbredelse og flere anvendelsesmuligheder og skifter status fra især at vare udtryk for en trend til at blive integreret $i$ det ungdomskulturelle hverdagsliv. Mobiltelefonen har i lobet af kort tid bidraget til en udvidelse og andring af rammerne for sociale relationer og kulturelle udtryk.

\section{Omfang og tidsbrug}

Som det fremgår af tabel 2, cr tclcfonen, både når det galder omfang og hyppighed i brug, en vigtigere kanal til kommunikation end Internettet i de unges tilvarelse. Fra 12 ar og op bruger alle telefonen, fem ud af syv dage i gennemsnit. Tidsbrugen stiger fra de 9-10-årige pigers otte minutters gennemsnitlige daglige snak til de 15-16-ărige pigers knap halve times samtaler. Dette korresponderer med informationerne fra den kvalitative undersogelse, hvor de yngste deltagere og mange af de aldre drenge siger, at de forst $o g$ fremmest bruger tele- 
fonen til aftaler, informationer eller kort kontakt med familicn. De bruger ganske enkelt ikke telefonen til at snakke i samme grad, som isar de store piger gor. Et eksempel er den 12-årige dreng, der dagligt ringer sin far op og siger »hej og så, ifolge faderen, ikke stort mere. Senere i artiklen beskrives den symbolske betydning af telefonsamtaler, her bekraftelsen af farens tilstedeverelse, der skal garantere trygheden for drengen, når han er alene hjcmme.

Udsagn fra undersøgelsen bekrafter de kvantitative datas antydning af, at det er kvinder, der sludrer i telefonen. Adskillige af deltagerne i undersogelsen siger, at det er deres mor/storesester, der sludrer med deres mor/soster/veninde i halve og hele vimer:

L. Altså min bedstemor, hun kan bare snakke i telefonen, det er sådan, at man kan blive helt rod i eret. Og også min mor og far, de kan bare aldrig holde op, også sidder hun der, helt fra min barnm dom og alt sådan noget... »åh, skal vi nu til det igen?

G: Altså med din mor, năr de snakker i telefonen? L: Ja, med min bedstemor. Det er sommetider mig, men min mor, hun bruger den helt vildt meget, for de snakker jo los, mest hende der Maria, min storesaste (Louise, 12 år).

Som det ses af tabel 2, taler pigerne fra 12-års-alderen dobbelt sa lang tid som drengene. Enkelte af drengene taler ogsa nogle gange i lang tid, men det er ikke nodvendigvis selvvalgt:

$\mathrm{J}$ : Der var engang, der gjorde jeg det rigtigt meget endda, det var engang da jeg var kereste med en, hun ringede jo hver dag, hun havde sin egen telefon oppe på loftet, og sá sidder hun der, og jeg kan huske, vi sad og snakkede en time hver dag, og de tre kvarter sad jeg bare: ???? ?, fordi forbindelsen var să dårlig, helt vildt, whvad siger du, hvad, hvad for noget? «, nej det var virkelig irriterende.

G: Hvis du skulle ringe op til en, altså til din kxereste, kunne du så finde pă noget at sige i en time? $\mathrm{J}: \mathrm{Na}$, nej (Jimmy, 15 år).

Drengene bruger nettet til flere ting end pigerne, og der er forskel på, hvor ofte, og i høj grad hvor lange drenge henholdsvis piger bruger Internettct. De 15-16-årige drenge bruger for eksempel i gennemsnit dobbelt så lang tid på nettet som pigerne, mens pigerne fra 12 års alderen bruger dob- belt så lang tid som drengene ved telefonen. Det er interessant, at ogsa andelen af piger, dcr overhovedet bruger Internettet, stiger med alderen og med $78 \%$ ligger forholdvis tat på drengenes $88 \%$ blandt de 15-16-årige. Når man ser på tidsbrugen, er der imidlertid markant forskel. Forskellen er også stor, năr det gælder, hvad man bruger Internettet til, bortset fra de aldstes brug af chat og e-mail. For eksempel chatter omkring $40 \%$ af báde de 15 16-årige piger og drenge. Til gengald er der flere bland de 12-13-ărige drenge, der chattcr, end pigerne i samme alder. Dette hanger formentlig sammen med, at de 12-13-ărige drenge på undersøgelsestidspunktet $\mathrm{i}$ højere grad end de jævnaldrende piger havde faet øjnene op for Internettet, og at drengene generelt bruger computeren mere, udforsker dens muligheder og foler sig fortrolige med den.

Den lille forskel i de 15-16-åriges brug af e-mail $k a n$ tolkes således, at drengene har aflost en storre del af telefonsamtalerne med e-post end pigerne har, set i lyset af pigernes lengere tidsbrug ved telefonen. Dette kan indikere, at telefonen især er pigernes medie. Der kan dog ogsa vare tale om endnu et udslag af drengenes hurtigere omstilling til ny teknologi, og dermed måske blot en udvidelse af kommunikationsmangden. Pigerne har jo netop også taget chat til sig som mulighed, selv om dette er en skriftlig kommunikationsform. Der er en rakke lighedspunkter mellem de karakteristiske trak ved telefonsamtaler mellem veninder og de temaer, der vendes i chatgrupperne og i chattens typiske sprogbrug (uformel person-til-person online samtale, fortrolighed og intimitet).

Med udbredelsen af mobiltelefonen bland store born og unge oges forskellene for hvor ofte, hvor meget og til hvad de enkelte bruger telefonen, idet stadig flere er frigjort fra foraldrenes kontrol af opringningeme. De skal forst stả til regnskab, når de skal have et nyt taletidskort, eller når regningen kommer, men den daglige brug kan almindeligvis ikke kontrolleres af forældrene. Mobiltelefonbrugen er ikke undersøgt systematisk, men for eksempel har flere dagblade foretaget rundsporger blandt born og larere for at fả et billede af omfanget. Et eksempel er offentliggjort i dagbladet Politiken, hvor en lacer fortaller om, at eleverne prasterer at ringe til hinanden under en bustur - fra sade til sxde, og hvor eleverne fortaller on, hvor ofte de bruger SMS-beskeder (Politiken 14.10.1999). 


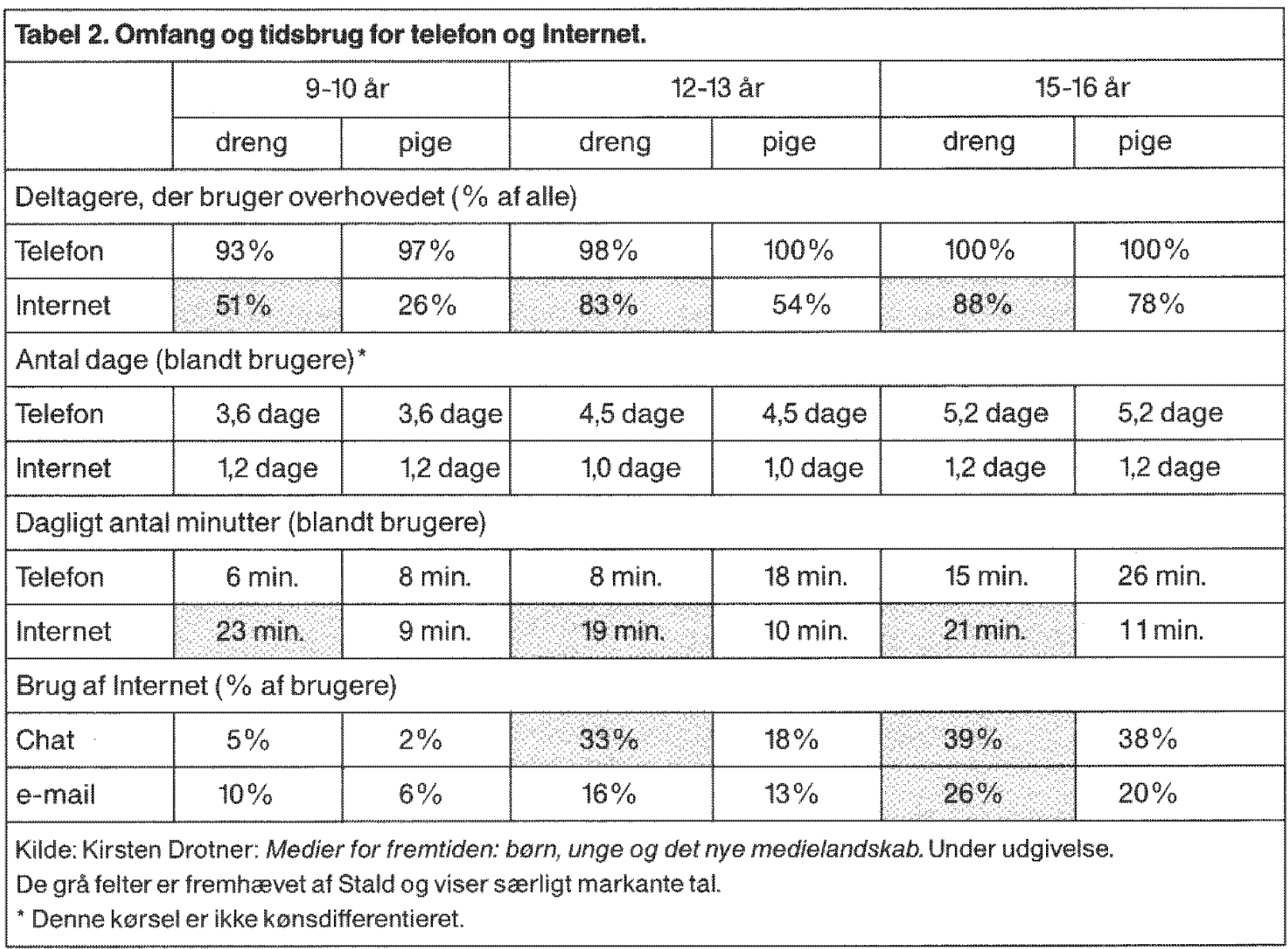

\section{Skitse til typologi for telefon og Internet}

Da medie- og kommunikationsforskningen ikke har fokuseret særskilt pä unges brug af informationsteknologi, er de teoretiske varktøjer til at analysere dette problemfelt tilsvarende begransede. Derfor har jeg i de folgende afsnit forsogt at systematisere en rakke karakteristika, der forbinder de typiske trok ved moderne informationsteknologi med den måde, hvorpå teknologien indgăr i unges kommunikationsmønstre og hverdagskulturer.

McQuail advarer mod at have en ren funktionalistisk tilgang til analyser af kommunikation og kommunikative processer, fordi kommunikation cr sa kompliceret og sammensat (McQuail 1989: 327,347 ). Han anbefaler i stedet, at man udvikler kategoriske rammer (frameworks) for hver case (McQuail 1989: 347). I det folgende opridses to sat typologicr, der dels viser telefonens og Internettets karakteristika som kommunikationsmidler, dels beskriver den konkrete og symbolske brug og betydning af telefonen og Internettet $i$ borns og unges universer. Typologierne er udformet pă bag- grund af eksisterende teori om interpersonel kommunikation (Gumpert og Cathcart 1986, McQuail 1989, Thompson 1995, Hjarvard 1997, Mayer 1997) samt pá baggrund af analyser af det empiriske materiale fra CUM's undersogelse. Typologierne er altsa skræddersyet til analysen i denne artikel.

De centrale kommunikationsformer, som for eksempel Stig Hjarvard opridser dem, fra interpersonel, ikke-medieret kommunikation til computeren (Hjarvard 1997: 10), karakteriseres af varierende mangde sammenfald, hvoraf de fleste findes mellem henholdswis telefon og computer. Computeren er det eneste medie, der dxkker alle de karakteristika, der samlet set findes ved de forskellige former for medieret kommunikation. Hjarvard finder frem til otte karakteristika ved medieret kommunikation, nemlig mulighed for gensidig udveksling, interaktion, tidsforskydning, tidssammenfald, ikke stedbundethed, punkt til punkt-kommunikation, massemedic, non-verbale udtryk. Kun i forhold til mulighed for tidsforskydning og massekommunikation adskiller telefonen sig fra computeren. Telefon og computer er de enc- 


\begin{tabular}{|l|l|l|l|l|}
\hline \multirow{2}{*}{ Figur 1. Telefon og Internet som kommunikationsmidler: typologil } \\
\hline MEDIE & \multicolumn{2}{|c|}{ TELEFON } & \multicolumn{2}{c|}{ INTERNET } \\
\hline $\begin{array}{l}\text { Tilstede- } \\
\text { værelse } \\
\text { mulighed }\end{array}$ & $\begin{array}{l}\text { kanal/ } \\
\text { teknologisk } \\
\text { mulighed }\end{array}$ & $\begin{array}{l}\text { kanal/ } \\
\text { teknologisk } \\
\text { mulighed }\end{array}$ & $\begin{array}{l}\text { kanal/ } \\
\text { teknologisk } \\
\text { mulighed }\end{array}$ & $\begin{array}{l}\text { kanal/ } \\
\text { teknologisk }\end{array}$ \\
\hline Tid & $\begin{array}{l}\text { synkron } \\
\text { asynkron } \\
\text { (SMS) }\end{array}$ & synkron & asynkron & synkron \\
\hline Rum/teknik & stedbunden & $\begin{array}{l}\text { ikke } \\
\text { stedbunden }\end{array}$ & $\begin{array}{l}\text { stedbunden } \\
\text { ikke } \\
\text { stedbunden }\end{array}$ & $\begin{array}{l}\text { stedbunden } \\
\text { ikke } \\
\text { stedbunden }\end{array}$ \\
\hline $\begin{array}{l}\text { Kommuni- } \\
\text { kation/ } \\
\text { interaktivitet }\end{array}$ & punkt til punkt & punkt til punkt & $\begin{array}{l}\text { punkt til punkt } \\
\text { punkt til flere }\end{array}$ & $\begin{array}{l}\text { punkt til } \\
\text { punkt } \\
\text { massemedie }\end{array}$ \\
\hline
\end{tabular}

ste af de nævnte kommunikationsformer, der dækker den ikke-medierede interpersonelle kommunikations fire karakteristika, nemlig muligheden for gensidig udveksling, interaktion, tidssammenfald og tilstedevarelse af non-verbale udtryk i kommum nikationen. Teoretisk er computeren således som kommunikationsmiddel betragtet en udvikling af telefonen. Hjarvard fremhever i indledningen til sin artikel netop to forhold. For det forste, at smediernes udvikling (kan) beskrives som en fortsat innovation, der bygger på lighed mellem de forskellige medier . For det andet, at sden interpersonelle kommunikation (kan) siges at udgore en særlig vigtig analogi, en grundform eller matrice, for de teknisk medierede kommunikationsformer (Hjarvard 1997: 5).

Objektivt set kan disse sammenfald måske angive en del af den betydning, såvel telefonen som computermedieret kommunikation har for brugerne. Hvis medieret kommunikation bygger på en matrice, der tager udgangspunkt i den mest grundliggende kommunikation, altsă den ikkemedierede interpersonelle samtale/relation, er der a priori en fortrolighed i forhold til den medierede kommunikation forudsat, at en ny fortrolighed kan etableres $i$ forhold til selve teknologien. For 100 a $\mathrm{r}$ siden havde bedstemor et sarligt, måske forskrakket eller arbodigt forhold til telefonen, i dag er det Intemettet, der udfordrer de aldre generationer, mens de yngre oftest hurtigt optager den nye teknologi i registeret af teknologiske muligheder. IIvis fortroligheden ikke alcne galder genkende- lighed i form og formål men også i oplevelse og resultat, må man antage, at medieret interpersonel kommunikation kan have samme funktion i forhold til intensitet, intimitet, emotionalitet som ikke-medieret interpersonel kommunikation.

Med andre ord kan kommunikation via telefon og Internet vare lige så betydningsfuld som kommunikation mellem personer, der er til stede i samme fysiske rum. Hermed argumenteres imod antagelsen om, at det omfang, telefonsamtaler og Internetkommunikation har for isar unge, i sig selv signalerer fremmedgørelse og skrak for de krav, sociale relationer i »real life « matte medfore.

Forskellen mellem kommunikation via henholdsvis telefon og Internet ligger i mediets karakteristika, der kendetegner produktion, formidling og reception af indholdet. Forst og fremmest produceres medieteksten i telefonsamtalen direkte af deltageme, og disse er bäde modtagere og afsendere. Dernast er der ingen eller fă muligheder (medhør, telefonmøder) for at opna falles erfaringer via den samme medietekst. for andre end de to deltagere, fordi teksten er simultan, ikke registreret (det vil i hvert fald vere en undtagelse) og situationsbestemt. De falles referencer, der kan omgive en telefonsamtale, findes på et generelt plan, for eksempel i form af en vis rituel brug af indledende og afsluttende udsagn, bestemte udtryk, turtagningsteknikker og sà videre alt efter, hvilken form for samtale, det drejer sig om. Og endelig tager samtalerne udgangspunkt i deltagernes mälrettede formăl med samtalen. En rakke al disse kam 
rakteristika dakker også online-kommunikation via Internettet, hvor teksten produceres direkte og cr situationsbestemt, ligesom der er en rakke ritualer, der omgiver kommunikationen. Derimod er online-kommunikation registrerbar som tekst og ofte åben for flere. Endelig mangler onlinekommunikationen telefonsamtalens sanselige karakter, dvs den verbale kommunikations lydlige udtryk. E-mails adskiller sig badde fra telcfonsamtalen og online-kommunikation ved sin tidsforskudte karakter, og ved at vare rettet fra person til person eller fra en person til flere. Emmails ligner imidlertid telefonsamtaler ved oftest at vare målm rettet mod bestemte modtagere.

De horisontale felter i figur I viser, at telefon og Internet betragtes som teknologisk mulighed for kommunikation, der er helt nodvendig i et moderne samfund, hvor man meget ofte ikke kan vare til stede samtidig som følge af den måde, hvorpå vi indretter vores dagligdag. At børn og unge også ofte valger teknikken frem for at opsøge modparten, ogsă når dette er muligt, begrundes dels i det praktiske ved den medierede kommunikation, dels ved de karakteristika, der gor telefonsnak eller Internetkommunikation til noget sorligt.

Tidssammenfaldet or specielt vigtigt for børn og unge, dels ved sxrligt målrettet kommunikation (aftaler, information), dels fordi muligheden for samtidig interaktion er en af telefonsamtalens og online-kommunikationens potentialer. Til gengaeld er stedbundethed eller ikke stedbundethed kun af ringe betydning, idet kormmunikationsmidlet, altså henholdsvis fastnettelefon, mobiltelefon, e-mail eller online kommunikation valges efter funktion og formål. Graden af stedbundethed far forst betydning i de tilfalde, hvor deltagerne ikke kan etablere det rum for kommunikation (for eksempel privathed, intimitet, som formálet med kommunikationen forudsætter. Betydningen af sted skal imidlertid også forstås som den næsten totale adskillelse af fysisk sted og socialt $n$ sted «, som Meyrowitz beskriver: "When we communicate through telephone, radio, television or computer, where we are no longer determines where and who we are sociallye (Meyrowitz 1985: 115). Herved ligestiller han indirekte betydningen af medierede henholdsvis ikke-medierede sociale relationer, hvilket ligger i trâd med en del af den nyeste forskning omkring sociale relationer i cyberspace (for ckscmpel SeftonmGreen 1998, Gotved 1999, Sjoberg 1999).
Alle fire kommunikationsformer muliggør punkt-til-punkt kommunikation/interaktivitet, mens e-mails udvider mulighederne til punkt-til-flere og online kommunikation muliggor massekommunikation.

\section{Brug og betydning}

Helt basalt handler telefonbrug og kornmunikativ brug af Internettet on at vare i forbindelse med andre. McLuhan peger pa, at sthe phone is a participant form that demands a partner, with all the intensity of elcctric polarity« (McLuhan 1964/ 1994: 268), og han tillægger således telefonen en kausalitet $i$ forhold til brugen: man kan ikke se en telefon uden at fă lyst til at bruge den. Funktionen fordrer interaktion, da der jo ikke er meget ved en telefon, hvis ikke der er to deltagere. Gumpert og Cathcart tager imidlertid snarere udgangspunkt i den behovsstyrede brug af telefonen. De havder, at enhver form for medieret kommunikation dybest set handler om kontakt mellem mennesker:

Every type of human communication, from faceto-face to mass communication, is still basically an interpersonal communicative act. This does not mean there is no need to study or understand communicative acts other than interpersonal, but rather that all human communication is, in the fim nal analysis, interpersonal (Gumpert og Cathcart 1986: 19).

Denne argumentation er udgangspunktet for synspunkterne i det felgende, idet det empiriskc materiale netop bekrafter, at born og unge grundlaggende har konkrete behov for kommunikation og sociale eller psykologiske behov, der blandt andet kan dxkkes af telefonens og Internettets symbolske betydning.

Grenserne mellem det konkrete og det symbolske plan, som de fremstilles, er flydende, idet der foregår en gensidig påvirkning mellem henholdsvis den konkrete brug og den symbolske betydning af brugen. For eksempel forer den helt konkrete udfoldelse af kontrol via telefonen til en folelse af kontrol, der virker tilbage på parterne enten som positiv psykologisk sikkerhed eller snarende forhindring. Tilvanningen til telefonen som sikkerhedsgarant bevirker til gengald til tider, at fraveret af telefonen befordrer en folelse af utryghed. 
Figur 2. Telefon og Internet i borns og unges univers: typologi II

\begin{tabular}{|c|c|c|c|c|}
\hline \multirow[b]{2}{*}{ BRUG } & \multicolumn{2}{|c|}{ TELEFON } & \multicolumn{2}{|c|}{ INTERNET } \\
\hline & konkret & symbolsk & konkret & symbolsk \\
\hline Tilstedevarelse & $\begin{array}{l}\text { kanal/ } \\
\text { teknologisk } \\
\text { mulighed }\end{array}$ & $\begin{array}{l}\text { statussymbol } \\
\text { makcot af } \\
\text { ungdoms } \\
\text { kunum } \\
\text { ldentitet }\end{array}$ & $\begin{array}{l}\text { Kanal } \\
\text { Ioknologisk } \\
\text { mulighed } \\
\text { integration al } \\
\text { funktioner }\end{array}$ & $\begin{array}{l}\text { statussymbol } \\
\text { markor af } \\
\text { modernitet/ } \\
\text { identitet }\end{array}$ \\
\hline Funktion & $\begin{array}{l}\text { Kommuni- } \\
\text { kation } \\
\text { (handling) }\end{array}$ & $\begin{array}{l}\text { kommuni- } \\
\text { kation } \\
\text { kontakn) }\end{array}$ & $\begin{array}{l}\text { kommuni- } \\
\text { kation } \\
\text { (handling) } \\
\text { datasøgning } \\
\text { datatrans- } \\
\text { mission } \\
\text { spil } \\
\text { design }\end{array}$ & $\begin{array}{l}\text { kommuni- } \\
\text { kation } \\
\text { (kontakt) } \\
\text { www-kontakt }\end{array}$ \\
\hline Betydning & $\begin{array}{l}\text { aftaler } \\
\text { information } \\
\text { udveksing/ } \\
\text { dialog } \\
\text { kontrol } \\
\text { sikkerhed } \\
\text { underhold- } \\
\text { ning }\end{array}$ & $\begin{array}{l}\text { bekraftelse } \\
\text { (kontrol) } \\
\text { trost } \\
\text { fallesskab } \\
\text { naervaer } \\
\text { (stemme og } \\
\text { budskab) } \\
\text { sikkerhed/ } \\
\text { tryghed } \\
\text { underhold- } \\
\text { ning }\end{array}$ & $\begin{array}{l}\text { aftaler } \\
\text { information } \\
\text { udveksling/ } \\
\text { dialog } \\
\text { netsurt } \\
\text { adgang/ } \\
\text { software } \\
\text { adgang/ } \\
\text { personer } \\
\text { skriflig } \\
\text { kommuni- } \\
\text { kation } \\
\text { prasentation }\end{array}$ & $\begin{array}{l}\text { bekroftelse } \\
\text { leg } \\
\text { leg med } \\
\text { identitet } \\
\text { naervaer } \\
\text { (kontakt og } \\
\text { budskab) } \\
\text { abent rum } \\
\text { (globalt) } \\
\text { intimt rum }\end{array}$ \\
\hline
\end{tabular}

\section{Kanal for kommunikation}

Konkret betyder tilstedeverelsen af telefonen, at man har en teknologisk mulighed for at kommunikere ualhæungig af sted. Traditionelt set har der ik ke været valgmuligheder i denne funktion, men det er der kommet i kraft af digitaliseringen, sâ man kan sende tekst- eller ikonbaserede beskeder, bede om tilbagekald, se nummervisning osv. Dog er det stadig opkald, modtagelse og samtale, der udgor telefonens vasentligste funktion. Det er, som vist i figur 2, kommunikation som handling. Den samme funktion har Internettet, men hertil kommer flere andre muligheder. E-mail kan fungere som $\mathrm{en} \mathrm{let}$ forsinket online-snak, men nettets særtrak er, at funktionen i hoj grad indrettes efter behovet. Endelig betyder Internettets primart skriftbaserede kommunikation (nettelefoner er stadig en sjalden- hed), at man er nodt til at kunne lase og skrive, og at man skal kunne forstå teksten.

Endelig er der en vesentlig forskel i, hvor opsogende man kan vare. Det er nogle år siden, Trafpunkt-numrene havde succes som forgangere for Internettets modesteder, kontaktannoncer og chat, men muligheden for at kontakte og mmode « nye mennesker via telcfonen eksisterer stadig, både via den almindelige adgang til offentligt tilgxengelige telefonnumre og i mere formaliseret form. For de unge idag er det imidlertid mere oplagt at vere opsøgende på Internettet, dels fordi der er så mange muligheder, dels fordi det er blevet et fenomen, der skal proves, og endelig fordi anonymiteten er bedre sikret på Internettet, end den er i telefonen.

Deltagerne i undersegelsen understreger i hoj grad tclefonens funktionalitet uanset hvilken be- 
tydning, den i øvrigt kan tillagges. I de fleste familier foregår en del af dagligdagens aftaler og informationsudvcksling via telefonen băde i familien og iforhold til andre. Derfor forekommer telefonen at vare uundvarlig i hverdagen.

Tegningen i figur 3 viser en 12-årig pige, der har tegnet sig selv i en dobbeltsikret position med den traditionelle telefon på bordet og mobiltelefonen i lommen. Til prasentationen horer forskelligt interiør, der matcher det, der faktisk findes i pigens hjem, som lampen og det lille bord med planten på. Under interviewet fortaller pigen, at hun godt kan lide at tale i telefon, og hun ringer jaevnligt til sine veninder for at lave aftaler med dem. Telefonen spiller en vasentlig rolle i familiens liv, dels for hendes fars arbejde, dels for hendes fortidspensionerede mors forbindelse til omverdenen. Hun har desuden tre xldre søskende, der er llyttet hjemmefra, og telefonen er et vigtigt redskab til, at familiens medlemmer kan holde sig gensidigt ajour med hinanden. ${ }^{3)}$
Drengen i nedenstående citat eksemplificerer den selvfolgelighed, telefonen betragtes med. Af eksemplet fremgår det, at mobiltelefonens betydning kan vare ganske jordbunden og ret să humoristisk:

G: Har I næsten altid mobiltelefon med, når I er ude?

$\mathrm{K}$ : Ja, så kan man bare ringe, og sige, at de skal satte kaffe over, dem, der er hjemme, min storebror er næsten altid hjemme. Så ringer vi og siger til ham, om han kan satte kaffe over.

G: Hvad gjorde I så, for I fik mobiltelefon?

K: Sa korte vi bare hjem.

G: Să måtte I selv lave kaffe?

$\mathrm{K}$ : Ja (frelles latter) (Kenny, 12 år).

\section{Kontrol og sikkerhed}

De fleste deltagere i undersøgelsen betragter som navnt telefonen som en nodvendighed, hvis fravar

\section{Figur 3.}

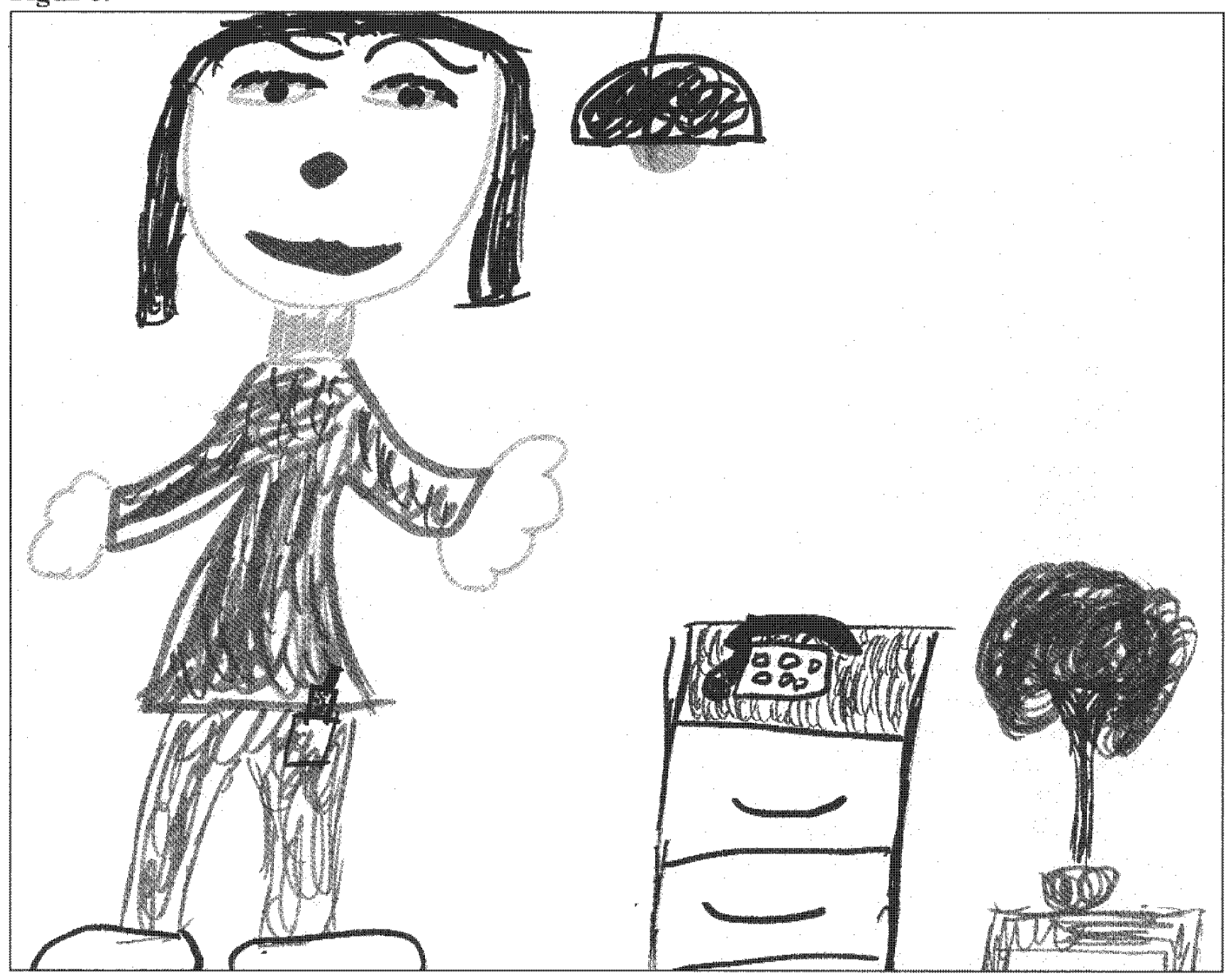


betyder fare og utryghed. Kun cnkelte siger som 12-årige Peter, at det kan vare rart at vacre fri for telefonen ind imellem:

G: Nảr I er på tur, så har I ikke telefon, så?

P. Nej, så har vi ikke telefon, så nyder vi, at vi ikke har tclefon, så det er fint.

Peter udirykker i hoj grad foreldrenes holdning, som pa den ene side er trukket konsekvent ned over ham, men som på den anden side også frigør ham for bekymring, idet foraldrene altså ikke mener, at der er grund til at anskaffe en mobiltelefon og tage den med alle vegne, men snarere, at fravaret er en frihed. Trods mange af forældrenes udsagn om, at telefonen ringer for meget, og at man er for alhangig af den, vil stort set alle imidlertid gerne have ekstensiv adgang til den både for sig selv og for bornene.

Mange af bornene betragter telefonen som en sikkerhed, selv om de tilsyneladende ikke har ople-" vet situationer, hvor det har varet afgorende at kunne ringe. Men de har hort om eller forestiller sig situationer, hvor telefonen kan betyde hjolp med det samme. 12-ảrige Kennys reaktion er tym pisk $i$ den henseende:

G: Hvorfor er telefonen vigtig for os alle sammen? $\mathrm{K}$ : Det er, fordi så kan man kontakte hinanden. Mobiltelefon, hvis der nu er vinter, og vi sidder fast ude i sneen med bilen, så kan man bare ringe.

Katrine pă 15 år fortwller: »Jeg skulle ned til et mode omkring Roskildefestivalen, og jeg var meget uvant med det og sădan noget, og der fik jeg den med, så jeg kunne ringe, hvis der var noget. Og det er også sådan, at mine søskende får den med ud, hvis de har et eller andet, de skal, der er vigtigt. Ellers har mor den med for det meste, så vi altid kan fa fat i hende, hvis der er noget «.

Eksempleme skal ikke bagatellisere den sikkerheds- og tryghedsmassige betydning, adgangen til for eksempel mobiltelefonen har for born og unge. De skal blandt andet pege pă, hvordan foreldrenes holdning til telefonens betydning påvirker bornenes holdning.

Mobiltelefonen kan ogsa opfattes som en helt konkret trussel, ifolge for ekscmpel den 15-årige pige, der har hort »det sidste nyek: at mobiltelefoner kan give kraft, fordi de afgiver nogle străler, eller den 9-årige pige, der har hort fra sine forældre, at det er farligt at talc i mobiltelefon, mens man kører bil.

\section{Symbolsk betydning}

Telefonen opfylder en rakke funktioner for brugeren ud over den konkrete som kanal for kommunikation, herunder flere, der knytter sig săvel til det at kommunikere som til mere symbolske betydninger. Sidney Aronson, der diskuterer de sociologiske aspekter af telefonen, men ikke eksplicit med henblik på børn eller unge, finder frem til de samme grundlaggende funktioner, som representeres i mit cmpípiske materiale:

The reduction of loneliness and anxiety, an increased feeling of psychological and even physical security and the already mentioned ability to maintain the cohesion of family and friendship groups in the face of residential and even geographic dispersion (Aronson 1986: 304).

Meyrowitz mener, at telefonen ligestiller os ved at bryde de traditionelle linexere hierarkier i vores hverdagskommunikation. I telefonen kan walmost. anyone ... speak to anyone« (Meyrowitz 1985: 161). Denne ligestilling forekommer at vare endnu storre i brugen af Internettet for dem, der kan lase og skrive, idet Internettet befordrer anonymitet $o g$ muligheden for at henvende sig til fremmede, for at henvende sig til mange og for at vaere opsegende eller distribuerende. I kraft af disse muligheder fungerer kommunikationsformernes indbyggede interaktivitet optimalt pa Internettet i forhold til telefonen, hvis man ser på funktionen og ikke de enkelte kommunikationssituationer. Den demokratiske funktion af telefonen og i endnu videre forstand computeren og Internettet, som for nogle forekommer at vare en trussel, er det horisontale mflow of informationk, vi kan fa uden at skulle igennem en rakke gatekeepers af autoriteter (Meyrowitz 1985: 322), hvilket han har direkte fra McLuhan (1964/1994: 273). Børn og unge har altså direkte adgang til udveksling af informationer.

Meyrowitz påpeger ogsă, at de yngste brugere, der ikke kan laese og skrive, făr en ny social mobilitet via telefonen. Når bornene mestrer teknikken og kan kommunikere mundtligt, far de lov til at deltage $\mathrm{i}$ telefonbrugen $\mathrm{i}$ familien og fär således mulighed for at udvide granserne for sociale relationer og erfaringer (Meyrowitz 1985: 81). 


\section{Bekraftelse af venskabs- og familerelationer}

Anthony Giddens diskuterer i Modernity and SelfIdentity sporgsmalet om, hvordan vi opfatter os selv i forhold til andre, og hvorledes denne opfattelse er afhengig af refleksivitet. Han taler om $»$ pure relations som de venskabsforhold, hvor venskabet i sig selv er det givende. Det er disse relationer, der er helt nodvendige for vores selvopfattelse i gensidige relationer (Giddens 1993: 88-98). Giddens mener, at seksuelle, agteskabelige og venskabelige relationer er »pure relations « for voksne, mens især relationer mellem foraldre og born er centrale for bornene. Dette må dog efter min mening udvides med venskaber for store børn og teenagere. Begrebet »pure relationship « diskuteres også af Lynn S. Clark i hendes artikel om net-dating:

Internet dating provides an illustration of the "pure relationship in its contemporary form. Yet Intemet dating relationship among teens also challenge Giddens' analysis, suggesting that our cultural understandings of the nature of relations" hips, and how they are evaluated in relation to issues of trust, commitment and longevity, may be changing in subtle and not fully emancipatory ways (Clark, 1998: 160).

Ifolge McQuail er venskaber både baseret på intimitet og på refleksivitet. Intrapersonel kommunikation reprasenterer selvets reflektioner over egen identitet ilyset af de signaler, der modrages udefra (»external communication «), og over egne tanker og ytringer. Den intrapersonelle kommunikation er săledes en vasentlig forudsatning for at kunne tolke sig selv i forhold til andre og dermed også en forudsatning for at kumne opretholde og udvikle disse venskabelige relationer (McQuail 1989: 23436). Telefonen bruges til stadigt at bekrxfte og afprove relationeme, når den hele tiden er $\mathrm{i}$ bevagelse med opkald mellem venner, der lige har set hinanden eller venner, der har måttet flytte fra hinanden, fra born til forældre pa arbejdet, mellem born og fraskilte fordeldre og mellem bom og andre familiemedlemmer. Telefonen bliver medium for bekreftelse i, at de nære relationer, og demed de involverede, stadig eksisterer, både set ud fra den enkeltes selvopfattelse og modpartens reaktioner som spejling af selvet. Den omfattende brug af SMS-beskeder blandt de store born og unge illu-

\section{Figur 4.}

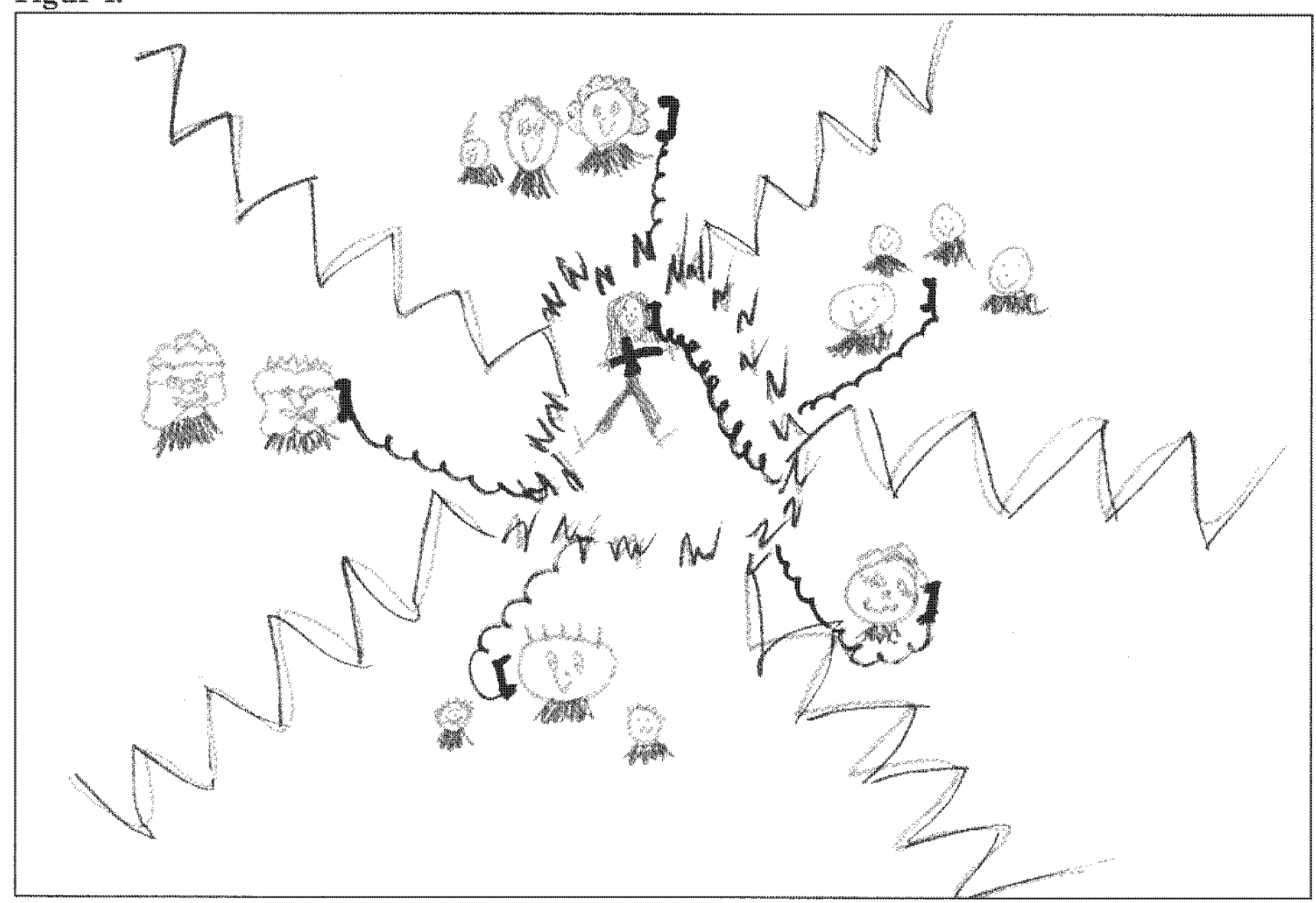


strerer eksplicit den symbolske betydning af telefonen i denne sammenhang.

Tegningen i figur 4 viser en 15-årig piges fremstilling af det telefonnetvark, der holder hende i forbindelse med diverse grene af familien. Hun sidder selv i midten, symbolsk markeret med et kryds, der udgor arme og krop, forbundet via den skitserede telefon ved hendes are og telefonledninger, der găr ud til forskellige medlemmer af hendes familie: bedsteforeldre, far og halvsoskende, moster, halvbror med familie samt vennerne. Hendes familieforhold er meget komplicerede, og en del ser hun meget sjeldent. Det savn, hun udtrykker under interviewet, afhjalpes i nogen grad via lange telefonsamtaler, der har en dobbelt funktion: såvel som livline for at kunne sfolge med « i hinandens tilvarelser, som at give mulighed for at vare txt pa i kraft af stemmernes reprasentation af personer, folelser og erindringer. Tegningen kan tolkes som et symbolsk edderkoppenet, hvor pigen sidder som en glad edderkop i midten og indfanger sbyttet i form af modtagerne eller samtalepartnerne, som dog alle tydeligvis er glade for »samtalen《. Kader man tegningen sammen med det, pigen siger om sin familie, foler hun sig som den, der har brug for at holde fast $i$ de andre, selv om vennerne $o g$ den hojt elskede moster ofte ringer.

Nogle gange er det en enkelt person, der betyder meget for en, og hvor telefonen kan give den narm hed, der skal til for at opretholde forbindelsen. Et eksempel er den 15-årige pige, der kun taler lang tid i telefonen med sin veninde, som er på efterskole. De ses hver anden weekend, når veninden er hjemme, men ind imellem tjener samtalerne om hverdagslivets oplevelser og overvejelser som bindeled săvel helt konkret i forhold til at holde sig orienteret om hinandens tilvarelse som symbolsk gensidig forsikring om, at man »er der .

\section{Fallesskab og narvaer}

I det citat, der indleder artiklen, sammenligner Mcluhan telefonens befordring af intimitet med det franske sprogs forening af wroice and eark. Meyrowitz betoner mere prosaisk, at sthe informality of electronic messsages is heightened when the medium is bidirectional and interactive. Speaking to someone on the telephone, for example, is so natural that we almost forget about the intervening medium « (Meyrowitz 1985: 109). På den ene side er marvaret bäde fysisk (overforsel af lyd) og sanseligt (perceptionen af de samtalendes stemme og ord, sansningen af telefon og lydbolger), et narvar, der befordrer intimiteten. På den anden side mener Meyrowitz, at det fysiske narvaer er ubevidst, så tilstedevarelsen af teknikken glemmes. Mobiltelefonen kan bidrage til at forstarke oplevelsen af intimitet, fordi hele mediet kan holdes i hånden og er i fysisk kontakt med ore og mund, og fordi den talende kan lukke sig inde i en fortrolighedsboble, selv i offentlige rum. Der opstår săledes en diskrepans mellem på den ene side overskridelsen af grænseme mellem det offentlige og det private rum med udbredelsen af mobiltelefonen og oplevelsen af intimitet på den anden side.

Gillard, Wale og Bow påpeger, at diskussionen om telefonbrug og om fysisk tilstedevarelse eller fravar $i$ en kommunikationssituation pparallels theoretical discussion about bodies, gender and identity, that are being provoked by newer forms of online communication, such as the Internet (Gillard, Wale og Bow 1998: 146).

Det er især de store piger i undersøgelsen, der opfatter telefonen som et medie, der muliggor en intim stemning mellem de to, der taler. Men det er meget vanskeligt at satte ord på for dem, der oplever denne intimitet:

G: Snakker man på en anden måde, når man snakker i telefon, end hvis man sidder og kikker pă hinanden, mens man snakker?

C. Ja, det tror jeg. Fordi at, jeg ved ikke, telefonen, det er sådan noget med, at... det ved jeg ikke. Det er nok, der kan man jo sidde og snakke, der kan man lukke sig inde i et rum, ikke, det kan man ogsin, når man sidder og snakker to og to, men der er det noget andet tror jeg, fordi der er man lidt mere sadan, der kan jo lige pludselig komme en brasende (Camilla, 15 ăr).

Camilla taler om både det fysiske rum, hun sidder i, når hun snakker i telefon, men også det symbolske rum, der kun vedrorer de to, der taler. Det er med andre ord et lukket rum, kun for de indviede. Meyrowitz mener, at telefonen giver mulighed for at etablere et lukket rum selv i andres narvar: ".. when two teenagers speak to each other on the telephone, they override physical distance and create a backstage area apart from the adults with whom they live (Meyrowitz 1985: 37). Telefonen bliver saledes et redskab til at markere tcenagernes sarlige univers, etablere sprivathed og lukke af for voksenuniverset. Det samme finder Patricia Gillard og hendes kolleger i deres undersogelse af anstralske teenageres telefonbrug: "Privacy was 
not defined by them as being at home but as having private conversations not overheard by other members of the household (Gillard, Wale og Bow 1998: 139).

Telefonens evne til at befordre en følclse af narhed kan imidlertid ogsă vare så påtrængende, at virkningen bliver den modsatte af de ovennavnte eksempler:

G: Har du skrevet brev til din mor, når du har vam ret på koloni, for eksempel?

R: Ja, det gar jcgaltid.

G: Du ringer ikke?

R: Jeg har opdaget, at hvis man ringer, så bliver man mere ked af det.

G: Nå, så kommer man til at savne mere?

R: Ja, jeg havde engang meget hjemve engang på skolens koloni, der ringede jeg ogsă, og så blev man endnu mere ked af det (Rasmus, 10 âr).

Jeg har ikke undersøgt indholdet i de enkelte telefonsamtaler, isar fordi der er bäde etiskc og metodologiske problemer i forhold til at indsamle materiale af denne type til egentlige indholdsanalyser. Mit kendskab til telefonsamtalernes indhold baseres derfor alene på det, deltagerne i undersogelsen har fortalt mig. Samme fremgangsmåde bruger Gillard og hendes kolleger i deres undersogelse af, hvad det er, de unge snakker om. I forhold til mit projckt er denne fremgangsmăde $i$ orden, mon en egentlig tekstanalyse vil kumne bidrage med viden om tematik, form og ikke-verbale udtryk og kan måske bidrage til en mere sikker analyse af sprog. brug, temaer, intimitet og fortrolighed i henholdsvis medierede interpersonelle santaler og ansigttil-ansigt-samtaler. Trods etiske forbehold vil det vare lettere at indsamle tekstmaterialet fra henholdsvis c-mails og chat end fra telefonsamtaler, men endnu er dettc kun gjort i beskedent omfang.

\section{Kulturel identitet og symbolsk betydning}

I figur 2 har jeg angivet den symbolske tilstedevarelse som statussymbol og/eller markor af ungdomskultur og identitet. For de 10-12-årige, er det smart nok, men i langden ogsă ret. uinteressant for kammeraterne, at man har en mobiltelefon. Men for en del af de aldste drenge (de 15-16-ärige og måske nogle lidt yngre) er det vigtigt at have den rigtige mobiltelefon, hvor storrelsen er omvendt proportional med potensen, og det er vig- tigt, at den har alle de sjove funktioner, der ligger ud over det funktionelle ved almindelig samtale. For pigerne er det $\mathrm{i}$ højere grad brugen af funktionerne, der er vigtige, selv om form, farve og vagt også gerne må være i orden. For fả år siden var det de, unge mand (og til dels kvinder), yuppierne, der gik rundt med de dengang dyre og sjaldne mobiltelefoner ved aret for at markere travlhed og bctydning. I dag er det betydeligt mere uchecket blandt voksne at gå rundt med sin telefon og ringe op eller modtage opkald offentligt, eftersom alle telefoner har en standby-funktion. I takt med at en stor del af befolkningen kan ringe hjem fra Brugsen for at hore, om det var sodmalk eller skummetmalk, der manglede, mister mobiltelefonen sin evne til at konnotere betydningsfuldhed. Til gengreld er mobiltelefonen blevet să almindelig, at den er ved at vare uundvarlig. For eksempel har cnhver håndverker med respekt for sig selv en mobiltelefon med rundt pa de skiftende arbejdspladser.

Der er ganske vist en tendens blandt en gruppe af deltagerne i undersogelsen til at mene, at det er de smarte, eller dem, der forsøger at være det, der går rundt og praler med sidste nye udgave af mobilen. Men generelt er der stadig blandt de store born og unge en fascination af mobiltelefonen både som teknik og som mulighed for hurtig kommunikation i enhver situation. Mobiltelefonen markerer tithorsforhold til en gruppe og bliver et element i det samlede billede af den unges sociale og kulturelle identitet. Og samtidig er mobiltelefonen isig selv să integreret $\mathrm{i}$ de unges medicunivers og kommunikationsformer, at også den bliver en selvfolgelighed. I naste omgang bliver det derfor formentlig nye integrerede funktioner, der $»$ triggerk fascinationen.

Der er ikke noget nyt $i$, at teenagere i hej grad bruger samtaler (sludder, pjat, betroelser, refleksioner) til at udforske sociale relationer og kulturelle udtryk og til at afprove egen identitet. Men modsat tidligere generationers begransede muligheder for medieret kommunikation i dagligdagen, foregår en stor del af kommunikationen i dag via elektroniske medier. En del foraldre i undersogelsen siger, at de ikke kan forstå, hvorfor ungerne ikke lige så godt kangå hen til hinanden i stedet for at ringe, og det or måske fornuftigt nok, når det galder do mindre borns aftaler. Men for de storre born og unge er det ikke et sporgsmål om, hvorvidt man vil se hinanden ansigt-til-ansigt, men om at telefonen har sin egen serlige rolle i de sociale relationer 
Figur 5.

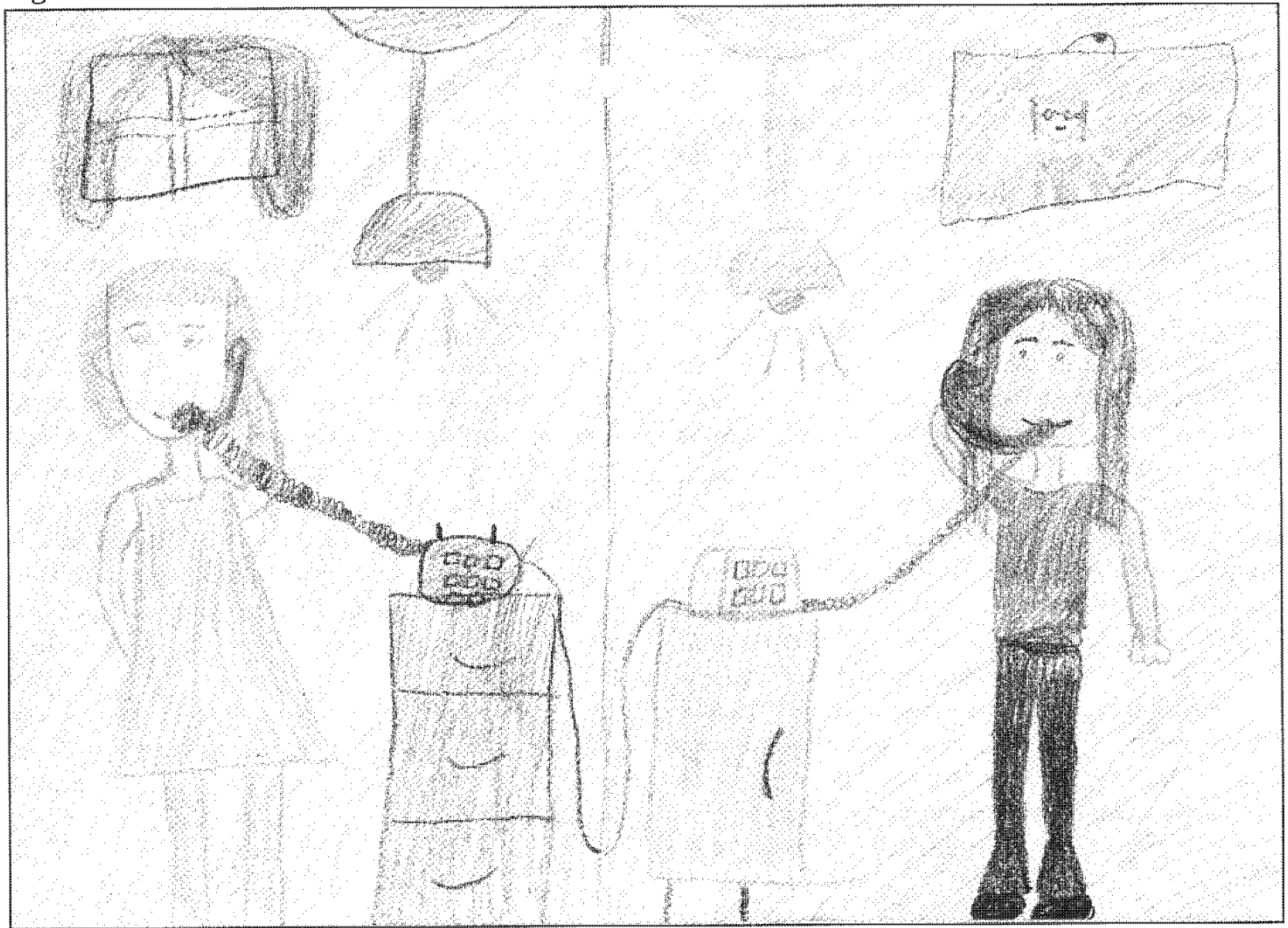

og kulturelle udtryk. Et eksempel er de to veninder pă tegningen i figur 5. De taler sammen i telefonen hver dag, ogsă selv om de mødes i skolen og i fritiden. I virkelighedens verden bor de ikke side om side, men her fremstilles afstanden symbolsk som varende meget kort, og de to piger og deres varelse/stue spejler sig i hinanden $i$ den symmetriske opbygning af billedets elementer. Pigerne kan identificeres som personer, ligesom rummene er personlige. Men den symbolske narhed og fallesskabet illustreres af spejlingen og i de symbolske »rums nærvær, kun adskilt af en streg/»vag«. Det er ikke de samme piger, men kunne vare det, som fortaller, at de ringer til hinanden hver morgen og snakker i lang tid, hworefter de går ned på gaden og moder hinanden for at følges i skole.

\section{Perspektiver: Nye medier, nye muligheder, traditionelle behov}

Telefonen cr bâde upåfaldende og en selvfolgelighed $i$ borns og unges tilvarelse. Som andre medier er telefonen integreret i hverdagslivet og har be- tydning for dannelsen af social, kulturel og psykologisk identitet. Pà dette niveau er telefonen et af mange medier, der har betydning for borns erfaringsdannelse og socialisation.

Der er ikke noget, der tyder på, at danske born og unge bruger informationsteknologien som redskab for kommunikation og relationer iVR (virtual reality), der skal crstatte IRL (in real life) relationer. Tvartimod ser det ud, som om telefonen i hoj grad bruges til at formidle og fastholde kontakter $\mathrm{i}$ et forvirret, fragmenteret hverdagsliv, og at telefonen fortsat er et centralt medium for - i flere henseender nodvendige sociale og kulturelle netvark

Mobiltelefonen har genoplivet en af den traditionelle telefons oprindelige funktioner som statussymbol (Aronson 1984: 304) og har samtidig forstarket den grundlaggende funktion, den traditionelle telefon altid har haft: det, at man uafhæengig af alstand kan komme i forbindelse med andre, $\mathrm{cl}-$ ler svare, năr andre vil i forbindelse med cn selv. For stadig flere voksne og teenagere foregår en dcl kommunikation imidlertid i Cyberspace, så man ikke alene kan vare uathaengig af rum, men også 
af tid. Alligevel har Internettets muligheder ikke i næwnevardig grad betydet en aflosning af andre elektroniske mediers servicer, men snarere en udvidelse af kommunikationsformerne og anvendelsesmulighederne, hvor den ene type kommunikation befordrer den anden, for eksempel opfolgning af online-kommunikation via telefon og IRL.

Chat er en af de nye former for kommunikation, der afproves af store born og unge. For alle chattere er udfoldesen af sig selv i det virtuelle rum et vigtigt element i en form for selvrefleksiv proces, hvor den enkeltes selvopfattelse og forhold til andre afproves, og hvor leg med identiteter er central (Sjoberg 1999: 26, Sorensen mfl. 2000: 65). Muligheden for at konstruere en fiktiv identitet uden (nødvendigvis) at blive stillet til regnskab for trovardigheden giver en frihed til at lege med flere identiteter, flere roller i det virtuelle rum og i det fysiske rum, mens man i virkelighedens verden er nødt til at trade ind og ud af de roller, man afprwver i forhold til sine omgivelser. Ifølge den engelske forsker Chris Abbott er Internettet imidlertid nnot so much [...] an alternative world but a setting where respite can be achieved and issues explored in comparative safety. It allows for complementarity rather than alterity (Abbott 1998: 97).

Online-kommunikation, hvilket for de fleste storre born og unge vil sige chat-rooms, men også MUDs og andre virtuelle rum for de mere avancerede brugere, gor det muligt at udfolde sig anonymt og uden den virkelige verdens begransnimger, og at udvide universet med nye bekendtskaber af fygtig eller varig karakter. Brugen af Internettet muliggor en åbning mod både lokal og global kommunikation og informations- og erfaringsudveksling:

G: Du sagde, at du godt kunne tænke dig at prove at skrive med en i et andet land over Internettet, hvad specielt er der ved det?

A: Det kunne da vare meget sjovt at finde ud af, hvad en i USA laver, ikke, i sin hverdag?

G: Men hvorfor er det specielt at gore det over Inm ternettet i stedet for at sende et brev?

A: Ja, for det forste găr det vel meget hurtigere, ikke? Men jeg ved ikke, om det er billigere. Lidt măske. Det koster jo penge at ringe op og sådan noget. Men det tager jo et par minutter, så er man i USA, det er også meget fascinerende. For eksempel, man kan sidde og spille skak med en fra Kina, altsă over computeren. Det er meget skagt (Anders, 12 år).
De unge, der javnligt deltager i bestemte chatrooms făr ofte en rakke netvenner, som de isar kommunikerer med. Forholdet til disse venner kan vare meget nært og af stor vigtighed i dagligdagen på linie med forholdet til »real-life« (RL)venner. Tilsyneladende opstär der ret hurtigt, når man etablerer »virtual reality« (VR)-venskaber, både en fortrolighed, hvor anonymiteten befordrer dybden af betroelserne og det folelsesmassige engagement, og et rum, hvor man er fri til at diskutere en lang rakke emner, der relaterer sig til såvel ungdomskulturelle fanomener som erfaringer og holdninger i almindelighed. Denne fortrolighed kan måske sammenlignes med den, der opstår mellem veninder i telefonen: en masse stomk hyggesludder og en hel del betroelser og informationsudveksling. Inderligheden i VR-venskabets betroclser kan også sammenlignes med tclefonsamtalens i visse situationer, men samtidig refererer Ulrika Sjoberg et eksempel fra et interview, som illustrerer, at nogle unge opfatter telefonen som et mere personligt medium end både det traditionelle brev og e-mail, idet stemmen - med ubevidst reference til McLuhan- befordrer folelsen af narkontakt. I tilknytning hertil påpeger Sjöberg, at det for de fleste born er lettere at udtrykke sig pracist i tale fremfor pả skrift (Sjöberg 1999: 234). Pointen er imidlertid, at formen influerer pă oplevelsen, både pa basis af de kompetencer, man har, og i forhold den konkrete simation.

Selv om storre born og unge i stort omfang har taget informationsteknologien til sig og har integreret den i hverdagslivet, diskuterer flere af deltageme i den danske undersøgelse forskellige perspektiver $\mathrm{i}$ den informationsteknologiske udvikling: pa den ene side synes mange af bornene og de unge netop, at informationsteknologien indeholder spandende muligheder og perspektiver, fordi den giver adgang til nye oplevelser og erfaringer. Dette underbygger tesen om, at born og unge ofte er de forste til at forsoge sig med nye muligheder, og at de hurtigt integrerer ny teknologi i dagligdagen som selvfolgeligheder. Pà den anden side ser de skrammebilledet, hvor de forstiller sig, at alle mennesker kun sidder foran en skarm og ikke laengere modes og snakker med hinanden. Dette udtrykkes også af deltagerne i Gillards undersogelse (Gillard, Wale og Bow 1998). Telefonen i sin traditionelle form opfattes ikke som en sădan trussel, mens en stigende digitalisering af medierne, der allerede har gjort brug af webcam og wephone mulig, ikke alene betragtes som et gode - heller ik- 
ke af dem, der er fascineret af computerteknologi i almindelighed.

Et par af pigerne i undersogelsen siger direkte, at de hellere ville ringe end bruge Internettet, hvis de skal i kontakt med nogen ude i den store verden. En af àrsagerne til denne holdning er manglende interesse for Internettets muligheder, og dermed den ekspansive mulighed, der ligger $i$ at kaste sig ud i åbent cyber-space. Fantasien rakker kun til, at man kommunikerer med folk i udlandet, man allerede kender. Den manglende interesse bunder for disse piger i en tat sammenkxdet kombination af manglende behov, erfaring og kompetence. Jeg vil imidlertid ikke foretage vidtrakkende konklusioner pă denne baggrund, idet erfaringerne med Internettet hele tiden udvikler sig, både i forhold til alder, kon og baggrund:

G: Kunne e-mail erstatte telefonen?

R: Măske kunne det, men jeg tror altså, jeg ville vare en af dem, der beholdt telefonen, klart. Jeg kan bedre lide ..., det er også sådan, når jeg skal sidde og skrive, nu er jeg heller ikke særlig god til at bruge et tastatur, det kan man selvfolgelig blive bedre til, men altså, også det, at man ikke bare kan snakkc, nu er jeg sădan en type, der snakker rimelig meget i skolen, jeg er kendt for at snakke rigtig, rigtig meget. ... Så jeg ville blive rimelig negativ, hvis man bare skulle sidde og skrive på en computer. Telefonen er en rigtig god opfindelse (Regitze, 12 ar).

På den ene side side tranger den informationsteknologiske udvikling sig pă med nye tilbud og muligheder. Pá den anden fastholder telefonen altså sin status som kommunikationsmiddel med en rakke specielle funktioner og betydninger. En forlge af udviklingen, der kan problematiseres er, at alle, men iser born og unge, i stadig højere grad kontrolleres og overvages via den evige mulighed for at kunne nås og at kunne nả. Fri-rummene skrumper ind, fysisk såvel som psykisk, når man altid kan kontaktes eller kontakte, og individualitet, frihed, demokrati i familierne, modenhed og sclvstandighed blandt danske born og unge er măske kun tilsyncladende i det øjeblik, børnene og de unge ikke kan tage stilling til noget som helst uden at hive mobilen op: sjeg ringer lige og horer «. Der sker en begraensning af den relative frihed, der er knyttet til den sikkerhedsfolelse, telefonen giver: sokay, ta' barc afsted, men tag mobiltelefonen med $\leftrightarrow$.

Samtidig er tidsfaktoren afgorende, fordi beho- vet for hastighed accelererer i takt med de teknologiske muligheder, der afsatter stress-spor i kolvandet. Et gennemgäende argument blandt bornene $o g$ de unge $i$ undersøgelsen for at bruge telefonen : stedet for at skrive breve er, at breve er for langsomme. Et argument for at bruge mobiltelefonen er, at man ikke behøver at vente med at ringe, til man finder en stationær telefon, et argument for at bruge e-mail til at kommunikere globalt, er, at det er hurtigt. Set i lyset af IT-udviklingen beholder telefonen indtil videre sin status såvel som medium for hurtige beskeder og aftaler (med e-mailens tidsforskudte kommunikation til sammenlig. ning), som for samtaler, der giver mulighed for gensidig meningsudveksling, refleksion og fordybelse (med traditionel ansigt-til ansigt-samtale og online-VR-samtaler som andre muligheder). Måske er moderne telefoner, såvel mobile som fastnet, inden for avanceret kommunikation pä vej til at udfordre mulighederne i straditionel computerm medieret kommunikation.

\section{Noter}

1. Artikelens empiriske basis udgores isar af data fra en undersogelse af danske bons og unges mediebrug financicet af TeleDanmark, Kultuministeriet og Staters Humanistiske Forskningsräd. Undersogelsen er del afet europaisk, komparativt projekt. whildren, Young People and the Changing Media Enviromment«, med deltagelse af forskcrgrupper fra 12 lande. Alle nationale teams har gennemfort kvantitative undersogelser og kvalitative interviews basenet på et falles rescarchdesign. Beskrivelse af det internationale projekt og en rakke midtvejsanalyser findes i et tomanummer af Eutopean Jouma of Communicalion (Livingstone 1998). Den kvalitative del af don danske undersogelse blev gennemfont af Gite Stald og omfatce interviews med 103 born og unge ligeligt fordelt pa aldersgruppeme 6-7 ar, $9-10$ år, 12-13 ar og 15m16 ar i to danske byer. Deltagerne blev spurgt om deres adgang til, brug af og holdmin ger til deres mediebrug (elektroniske suvel som trykte medier). Alle born blev observeret i deres klasse i skolen og dernast interviewet i grupper pun seks borm opdelt idrenge og piger for $s i g$. 48 af disse born blev derefter interviewet individuelt pa deres vaerelse i hicmmet, og naster alle foreldre til disse born blev efterlolgende intervicwet. Larere, skolc. ledere, medielarere og skolebibliotekarer blev interviewet. Endelig blev de yngste born observeret i deres frividskubber. Bornene reprasenterer en bredt defineret gruppe af almindelige born i Danmark, herunder ogsa born af anden etnisk oprindelse end dansk, hvis de gik i de besogte klasser. Den kvantitative del af undersogelsen, som omfattede 1349 
barn isamme aldersgrupper, blevindsamlet i marts 1998 af Socialforskningsinstituttet. Den samlede danske undersøgelse udgives i Drotner 2000.

2. IOstrig markedsfores mobiltelefonen $\mathrm{B}$-free $\mathrm{Kid}-$ Das Handy nur fur Kads - for eksempel pa det ostrig." ske teleselskab Mobilkoms hjemmeside: Den Robin Hood-gronne telelon med farvestrálende taster prasenteres af en frisk karatesparkende 10-årig dreng med gron-gule sommerfuglevinger, der matcher telefonens farver. Telefonen presenteres som vaerende handy for born, nem at bruge, og som et helt nodvendigt sikkerhedsudstyr for moderne born.

3. Deltagerne i den kvalitative del af den danske unm dersogelse blev bedt om at tegne sig selv, mens de brugte et eller flere medier ffer eget valg, alene eller sammen med andre, et sted efter eget valg. 97 tegninger udgor en del af materialet for den samlede undersogelse.

\section{Litteratur}

Abbott, Chris (1998) making Connections: Young

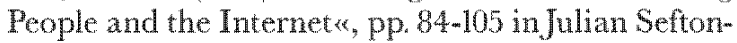
Green (red) Digital Diversions: Now Culture in the Age of Multimedia London: UGL Press.

Aronson, Sidney H. (1986) "The Sociology of the Talephone Cathcart (red) Inter/Media Oxford: Oxford University Press.

Clark, Lynn Scofield (1998) wDating on the Net: Teens and the Rise of $*$ Pure Relationshipse, pp. 159 m 83 in Steven $\mathrm{G}$. Jones (red) Gybracinty 20. Revisiting CompuLer-Mediated Communiration and Commurity London: Sage.

Danmarks Statistik (2000) Pcere og adgang ba Internet 2000 http//www.dst.dk/internet2000.

Drotner, Kisten (2000) Medier for fremtiden: bow, wng og det me medielandshab Under ndgivelse.

Fridberg, Torben (1999) Skolebans fritidsakiviteter. Kulturog fridsaktivitetsundersagelsen 1998 Kobenhavn: SEL.

Giddens, Anthony (1992) Modomity and Self-Identiv Cambridge: Polity Press.

Gillard, Patricia, Karen Wale og Amanda Bow (1998)

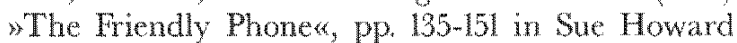
(red) Wred Lp: Young People and the Electronic Media London: UCL Press.

Gotved, Stine (1999) Cybersociologi: det samme pá en anden made Sociologisk Institut, Kobenhavns Universitet. Ph.d.-athandling.

Gumpert, Gary og Robert Cathcart (1986) mIntroductionw og ;The Interpersonal and Media Connectionk, pp. 9.25 in Gart Gumpert og Robert Cathcart (red.) Inter/Meda Oxford: Oxford University Press.
Hjarvard, Stig (1997) simulerede samtaler" om forhodet mellem interpersonel kommunikation og medieCormidlet kommunikation, Medie Kullur 26:5-17.

Intemational Telecommunication Union (2000) ITU TELecommunation Imdicators. http://www itu int/i/ndustryoverview/index, htm

Livingstone, Sonia (1998) (red.) ) Young People and the Changing Media Environment, European Joumal of Conmunication 13,4 .

Mayer, Paul A. (1997) wypologies for the Analysis of Computer Media , Convergence 3, 2: 82-101.

McLuhan, Marshall (1994) Understanding Media Massam chusetts: MIT Press. Opr. 1964.

McQuall, Denis (1989) \#Functions of Communication: A Nonfunctionalist Overviewa, pp 327-49 in Charles R. Berger og Steven H. Chalfee (red.) Hondbook of Communication Science London: Sage.

Meyrowitz, Joshua (1985) No Sense of Place: The Impact of Electronie Media on Social Behavior Oxford: Oxford University Press.

Nissen, Jörgen (1998) "Hackers: Masters of Modernity and Modern Technology" pp. 149.71 in Juhan Sefton-Green (red.) Diginal Diversions. Fouth Culture in the Age of Multimedia London: UCL Press.

Whedsbren (1999) Kobenhavn: Vibenshus skole: januar.

Politiken (1999) sektionen w Computer : 14.10.

Pool, Ithiel de Sola (1977) "Introductione, pp. 1.9 in Ithi a de Sola Pool (red) The Social Mmpact of the Telephone Cambridge, MA: MTT Press.

Sefon-Green, Julian (1999) "Introduction: Being Young in the Digital Age , pp. 1-20 in Julian Sefton-Green (red) Digital Diverstons: Youth Culwe in the Age of Mullmedia London: UCI Press.

Sjoberg, Ulrika (1999) mAt leva i Cyberspace , pp. 13-33 in Christa L. Christensen (red) Bum, unge og medier: nondiske forshingsperspektiver Goteborg. Nordicom.

Stald, Gitte (1997) Bum og unge foran sharmen. rapport Kobenhava: Center for Borne- og Ungdomsmedicr, Kom benhavas Universitet.

Stald, Gitte (1998) »Living with Computers Young Danes' Uses of and Thoughts on the Uses of Computers pp. $199-228$ in Stig Hjarvard og Thomas Tufte (red.) Sekvens: learbook 1998. Audioutsual Media in Transition Institut for Film- og Medicvidenskab, Kobenhavns Universitet.

Sorensen, Birgite Holm, Birgitte R. Olesen og Lone Audon (2000) »Legekulur pa chatkanalerne«, pp. 55-83 in Birgitte Holm Sorensen og Birgite R. Olesen (red) Bom i en digital hulur: forkning perspektiver. Kobenhavn: Gads Forlag.

Telestyrelsen (1999) Tele 98: telearbog Danmank Kobenhavn: Telestyrelsen.

Thompson, John B. (1995) The Media and Modernity: A. SocialTheory of the Moda Cambridge: Polity Press. 


\title{
Unge i en risikogruppe og deres mediebrug: en undersøgelse af mediebrug blandt 15-18-årige uden for uddannelse og job
}

\author{
Per Schultz Jørgensen
}

Unge uden uddannelse er en udsal gruppe i en verden, der mere end nogensinde lagger vogt pä kvalifikationer og kompetence hos den enkelte. De vil komme til at stä uden de formelle forudsetninger, der skal til for at skabe sig en selustondig tilverelse. Men ogsà ofte uden-eller med suagere-uformelle netverk, der giver styrke, tilskyndelse og forankring. Derfor er det en nerliggende antagelse, at unge, der ikke kommer igang med en uddannelse i de vigtige ungdomsair, befinder sig i en sairbar position: de star uden for uddannelsesarenaeme og kan ende som en egentlig uddannelsesmassig restgruppe." Flere undersogelser fra de senere är behrafter en sädan antagelse (Jensen mfl. 1997).

Den foreliggende undersogelse vil give et bidrag til belysning of denne gruppe unge, der ikke på undersegelsestidspunktet var $i$ gang med en uddannelse og heller ikke var $i$ arbejde. Undersogelsen vil belyse denne gruppes sociale situation og dens brug af medier.

\section{Hvem er den uddannelses- massige risikogruppe?}

Iden forste landsdakkende undersogelse af danske unges samlede mediebrug (Fridberg mfl. 1997) omfatter risikogruppen af unge fire procent - eller mere pracist 63 unge - med en nogenlunde ligelig fordeling af mand og kvinder. Denne gruppe omfatter unge, der har afsluttet et skoleforlob men uden af vare (a) i gang med en erhvervsuddannelse eller (b) i job.

De har for langt de flestes vedkommende afsluttet skolen fra 9. eller 10. klasse. Det gæelder for 95 procents vedkommende. De resterende har enten et uafsluttet gymnasicforløb ( 1 person) eller uafsluttet hf-forlob (1 person) bag sig. Men hvad er så deres beskxftigelsesmessige situation? Det viser sig, at den storste del af gruppen er registreret som arbejdslose.

At vare arbejdslos kan dakke over mange forskellige situationer, når man er $\mathrm{i}$ aldersgruppen $15-18$ å - fra at vare $i$ en venteposition eller uafklarethed til reelt at stá i kø for at fa et job. Når man derimod or i en slags offentligt tilbud, i en stotteordning eller uden indkomst begynder situationen mere klart at fa karakter af sårbar position. Denne situation befinder omkring 40 procent af gruppen sig i (jvit tabel 1):

De unges boligmassige situation er den, at tre ud af fire bor hjemme hos foraldrene (75 procent). En del har egen bolig (11 procent), andre er pă uddannelsesinstitution ( 5 procent) eller svarer sandet« på sporgsmålet om bolig (10 procent). Sảan ser den uddannelsesmassige risikogruppe af unge ud, der skal yderligere belyses i det folgende.

\begin{tabular}{lr}
\hline $\begin{array}{l}\text { Tabel 1. Risikogruppens beskeltigelses- } \\
\text { massige situation. Pct. }\end{array}$ \\
\hline arbejdsløs & 37 \\
beskæeftigelsestilbud & 10 \\
bistandshjelp & 8 \\
uddannelsestilbud & 6 \\
uden job, udd. eller indkomst & 16 \\
andet & 24 \\
\hline I alt & 101 \\
\hline $\mathrm{N}=63$ & \\
\hline
\end{tabular}

